\title{
A Rapid Method for the Selection of Amidohydrolases from Metagenomic Libraries by Applying Synthetic Nucleosides and a Uridine Auxotrophic Host
}

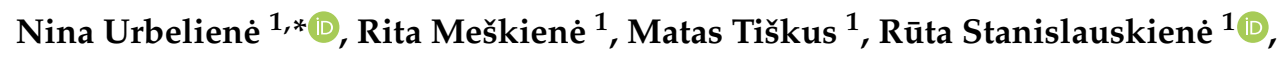 \\ Agota Aučynaitè ${ }^{1}$, Audrius Laurynènas ${ }^{2}\left(\mathbb{D}\right.$ and Rolandas Meškys ${ }^{1}$ \\ 1 Department of Molecular Microbiology and Biotechnology, Institute of Biochemistry, Life Sciences Center, \\ Vilnius University, Sauletekio av. 7, 10257 Vilnius, Lithuania; rita.meskiene@bchi.vu.lt (R.M.); \\ matas.tiskus@gf.stud.vu.lt (M.T.); ruta.stanislauskiene@bchi.vu.lt (R.S.); Agota.Aucynaite@bchi.vu.lt (A.A.); \\ rolandas.meskys@bchi.vu.lt (R.M.) \\ 2 Department of Bioanalysis, Institute of Biochemistry, Life Sciences Center, Vilnius University, \\ Saulètekio av. 7, 10257 Vilnius, Lithuania; audrius.laurynenas@bchi.vu.lt \\ * Correspondence: nina.urbeliene@bchi.vu.lt; Tel.: +37-052234395; Fax: +37-052687009
}

Received: 14 February 2020; Accepted: 18 April 2020; Published: 21 April 2020

check for updates

\begin{abstract}
In this study, the development of a rapid, high-throughput method for the selection of amide-hydrolysing enzymes from the metagenome is described. This method is based on uridine auxotrophic Escherichia coli strain DH10B $\triangle p y r F E C$ and the use of $N^{4}$-benzoyl-2'-deoxycytidine as a sole source of uridine in the minimal microbial M9 medium. The approach described here permits the selection of unique biocatalysts, e.g., a novel amidohydrolase from the activating signal cointegrator homology $(\mathrm{ASCH})$ family and a polyethylene terephthalate hydrolase (PETase)-related enzyme.
\end{abstract}

Keywords: metagenomic libraries; amidohydrolase; amidase; selection method; high-throughput screening

\section{Introduction}

It is estimated that the Earth is inhabited by $10^{11}-10^{12}$ microbial species, of which only $\sim 10^{4}$ have been cultured in the laboratory [1]. Nonetheless, the unculturable microbiome has provided science with new genes, biocatalysts, natural compounds, and bioproducts [2-5]. New enzymes that could allow provide novel approaches for designing enzymatic processes are in constant demand, and so are the screening methods for them. Keeping in mind that the functions of $30 \%-40 \%$ of the genes in genomes remain unknown, the detection of new biocatalysts in the sequenced genomes can be difficult if no significant homology with known enzymes is observed [6,7]. Metagenomics, the improvement of high-throughput screening methods, and the development of host expression systems for metagenome-derived genes, systems biology, and gene synthesis may together open the gateway to the useful information that hides in unexplored genetic resources, e.g., new enzymes with unique properties and novel scaffolds applicable for evolution in vitro [8-12].

The amidohydrolases/amidases are large classes (EC 3.5.1 and 3.5.2.) of enzymes which hydrolyse a wide variety of linear and cyclic amides. These enzymes are involved in several metabolic pathways, e.g., amide digestion and absorption by breaking carbon and nitrogen bonds, prokaryotic amide degradation, and synthesis of many important eukaryotic growth factors. Amidohydrolases have potential applications in chemical synthesis, pharmaceuticals, and effluent treatment due to their remarkable chemo-, regio-, and enantio-selectivity. At present, amidases are used for the biosynthesis 
of $\beta$-lactam antibiotics [13], and the production of (S)-4-fluorophenylglycine (a chiral intermediate for the synthesis of antiemetic drugs) [14], nicotinic [15] and 2-chloronicotinic acids [16], and the herbicide L-phosphinothricin [17]. L-asparaginase and L-glutaminase are used as oncolytic enzymes [18], and in the food industry for the production of acrylamide-free food (to reduce the formation of acrylamide during the frying of starchy foods at high temperatures) [18].

Several approaches for functional screening of amidohydrolases in metagenomes have already been described. Chemical compounds, e.g., phenylacetyl-L-leucine or D-phenylglycine-L-leucine [19], racemic tert-leucine amide [20], and L-phosphinothricin [21] can be used as the only nitrogen sources in minimal medium to isolate bacterial strains or enzymes that have amidase activity. Bacterial gene libraries, constructed from an environment intentionally enriched in $N$-acylhomoserine lactone-degrading bacteria [22], have been used as well. The acyl transfer activity of amidase in the presence of hydroxylamine, resulting in the spectrophotometric quantification of hydroxamic acid/iron(III) complexes, as well as the whole-cell methods that use the chemical properties of one of the products formed in the amidohydrolase enzymatic reaction to form coloured complexes with stable iron salts have been proposed $[23,24]$. A system that is based on pro-chromogenic substrates combined with an auxiliary enzyme [25] and an effective approach based on product detection-the product-induced gene expression (PIGEX) [26] system—have also been reported to be suitable for screening of amidohydrolases in metagenomes.

Recently, it has been shown that a uridine auxotrophic strain of Escherichia coli can be successfully used for the identification of certain enzymes involved in the catabolism of modified heterocyclic bases or nucleosides [10,11,27] and for functional screening of esterases [12], when the appropriate uracil or uridine derivatives serve as substrates for the enzymes. Here, we present a method based on uridine auxotrophic E. coli, tailored especially for the selection of amidohydrolases from metagenomes.

\section{Results and Discussion}

\subsection{Functional Screening of Metagenomic Libraries}

To develop this selection method, $N^{4}$-benzoyl-2'-deoxycytidine (4) was used as a sole source of uridine in the minimal M9 medium for the E. coli DH10B $\triangle p y r F E C:: \mathrm{Km}$ [27] strain, harbouring plasmid vectors with random environmental DNA fragments (the metagenomic libraries). The amidohydrolases, supposedly encoded in the metagenomic libraries, convert $N^{4}$-benzoyl-2'-deoxycytidine to 2 '-deoxycytidine, and the native E. coli cytidine deaminase [28] converts $2^{\prime}$-deoxycytidine to $2^{\prime}$-deoxyuridine, upon which the growth phenotype of uridine auxotrophic cells is restored. The principle of the selection method is shown in Figure 1.

Metagenomic libraries used for functional selection of amidohydrolases were constructed from different soil DNA samples as described earlier [12]. The DNA fragment length varied from 5 to $17 \mathrm{~kb}$ in the different libraries. In total, 15 libraries were tested. The positive hits were identified in 5 of these libraries (Table S1). The clones encoding the desired amidohydrolases were selected using M9 medium containing $100 \mu \mathrm{g} / \mathrm{mL}$ ampicillin, $40 \mu \mathrm{g} / \mathrm{mL}$ kanamycin, and $20 \mu \mathrm{g} / \mathrm{mL} N^{4}$-benzoyl-2'-deoxycytidine (4). In overall, approximately $10^{6}$ clones were analysed on a single agar plate. Altogether, 12 positive clones were selected. To omit the false positive hits, all clones were re-streaked on M9 medium with and without the cytidine derivative. Plasmid DNA was isolated only from the clones forming colonies in the presence of $N^{4}$-benzoyl-2'-deoxycytidine, and restriction analysis was carried out to exclude the recurring ones. Therefore, 7 plasmids were chosen for further analysis. $N^{4}$-benzoylcytidine (12), instead of $N^{4}$-benzoyl-2'-deoxycytidine (4), was also tested as a substrate-all 7 E. coli DH10B $\triangle$ pyrFEC::Km transformants harbouring the selected plasmids used the $N^{4}$-benzoylcytidine (12) as a uridine source. The necessity of the auxiliary enzyme for successful selection was demonstrated by deletion of the E. coli cdd gene, which encodes cytidine deaminase. As expected, none of the selected plasmids complemented the uridine deficiency in E. coli DH10B $\triangle p y r F E C c d d:: \mathrm{Km}$-the cells did not grow on the M9 agar medium supplemented with $N^{4}$-benzoyl-2'-deoxycytidine (4) (Figure S1). 


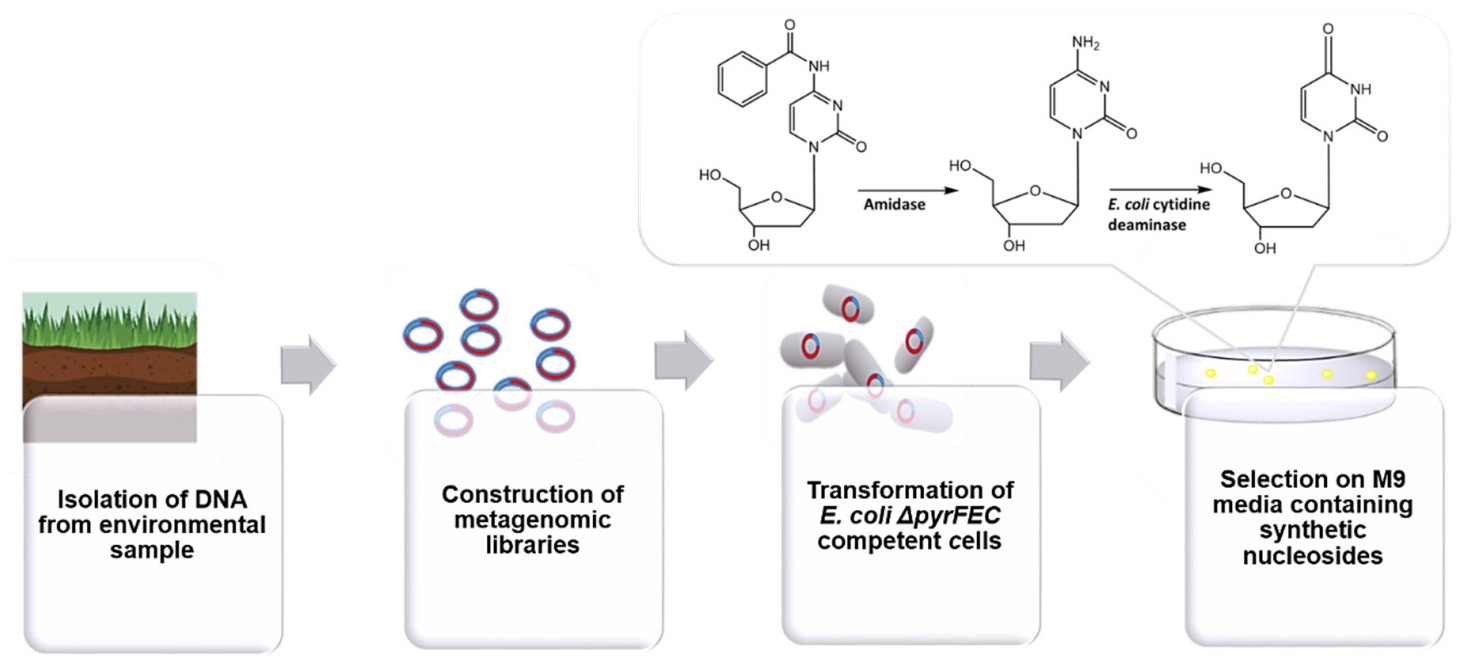

Figure 1. The principle of amidohydrolase selection. Metagenomic DNA isolated from the environmental samples is fragmented, inserted into an appropriate plasmid vector, and used to transform the competent Escherichia coli DH10B $\triangle$ pyrFEC::Km cells. Mineral M9 medium containing $N^{4}$-benzoyl-2'-deoxycytidine as a sole source of uridine is used to select the clones harbouring the amidohydrolase activity: amidohydrolases convert $N^{4}$-benzoyl-2'-deoxycytidine to $2^{\prime}$-deoxycytidine, which is then converted to $2^{\prime}$-deoxyuridine by the native E. coli cytidine deaminase. The positive hits complement the growth of uridine auxotrophic E. coli DH10B $\triangle p y r F E C:: \mathrm{Km}$ strain, allowing the formation of colonies.

\subsection{Bioinformatic Analysis of the Selected Clones}

The sequence analysis showed that 6 of the 7 selected clones contained ORFs with medium (40\%) to high (99\%) sequence identity to hydrolases found in the NCBI GenBank database [29] (Table 1). The clone P4FUMM07 contained two ORFs ( $80 \%-84 \%$ identity) encoding potential amidohydrolases, which were therefore named P4FUMM07_AcAm and P4FUMM07_AmH.

Table 1. The list of selected amidohydrolases and their nearest homologues.

\begin{tabular}{|c|c|c|}
\hline $\begin{array}{l}\text { Selected Amidohydrolase, } \\
\text { GenBank Accession No. }\end{array}$ & $\begin{array}{l}\text { The Nearest Homologue Genus/Species, } \\
\text { GenBank Accession No., Protein Name }\end{array}$ & Identity $(\%)$ \\
\hline BRM_Am, MN734430 & Pseudomonas sp. 1 R 17, WP_065947988.1, amidase & 99 \\
\hline K3_Am, MN734429 & $\begin{array}{c}\text { Achromobacter xylosoxidans, WP_013394140.1, } \\
\text { amidase }\end{array}$ & 97 \\
\hline MO10_Am, MN734431 & $\begin{array}{c}\text { Rhodococcus erythropolis, WP_084324709.1, } \\
\text { amidase }\end{array}$ & 99 \\
\hline P4FUMM07_AcAm, MN734432 & Agromyces sp. Root80, Wp056655740.1, amidase & 84 \\
\hline P4FUMM07_AmH, MN734432 & Agromyces sp. Root81, Wp056655731.1, amidase & 80 \\
\hline CIAN4, MN734434 & $\begin{array}{c}\text { Pusillimonas noertemannii, PVY61383.1, feruloyl } \\
\text { esterase }\end{array}$ & 73 \\
\hline MO13_Est631, MN734432 & $\begin{array}{c}\text { Bacillus asahii, WP_119118064.1, tannase/feruloyl } \\
\text { esterase family alpha/beta hydrolase }\end{array}$ & 56 \\
\hline D8_RL, MN734435 & $\begin{array}{c}\text { Runella limosa, WP_028525627.1, hypothetical } \\
\text { protein }\end{array}$ & 40 \\
\hline
\end{tabular}

The phylogenetic analysis of the selected hydrolases showed that these enzymes belong to various groups of proteins (Figure 2 and Figure S2). Four of these enzymes (BRM_Am, MO10_Am, K3_Am, and P4FUMM07_AcAm) belong to the amidase signature (AS) enzyme superfamily SSF75304. According to the Uniprot database [30], the amidase signature (AS) enzymes are a large group of hydrolytic enzymes that catalyse the hydrolysis of amide bonds and have diverged widely with regard to 
substrate specificity and function [31]. Examples of AS enzymes include peptide amidase [32], fatty acid amide hydrolase [33], malonamidase E2 [34], and subunit A of Glu-tRNA(Gln) amidotransferase [35].

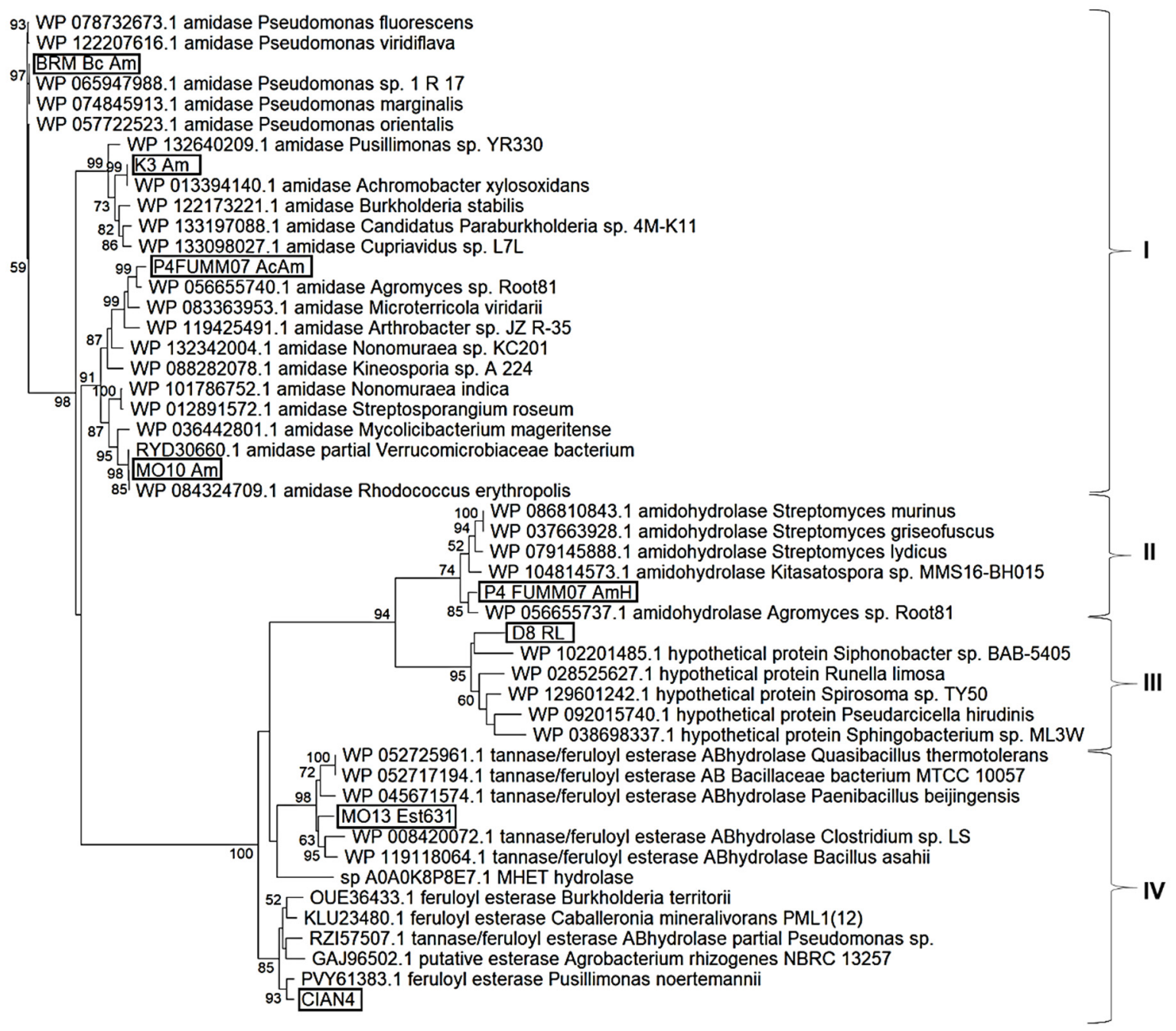

Figure 2. Phylogenetic tree of the selected amidases. The NCBI Database attributes the 8 selected hydrolases to 4 different superfamilies: I-amidase signature (AS) enzymes (SSF75304), II—-metal-dependent amidohydrolases (SSF51338; SSF51556), III—uncharacterized, activating signal cointegrator homology (ASCH) domain-containing proteins, and IV_ABhydrolases (SSF53474). The phylogenetic analysis of metagenome fragments was conducted using the Maximum Likelihood Tree routine of MEGA 10 software. The alignment was performed using ClustalW. The tree with the highest $\log$ likelihood (-33188.94) is shown. Only bootstrap values higher than $50 \%$ are indicated. The enzymes identified in this study are boxed.

P4FUMM07_AmH is a representative of metal dependent amidohydrolase superfamilies SSF51338 and SSF51556. Members of these superfamilies of proteins participate in a large number of processes including nucleotide metabolism, detoxification, and neuronal development [36,37].

MO13 and CIAN4 are representatives of ABhydrolase superfamily SSF53474 and belong to the group C of the tannase/feruloyl_esterase family [38,39]. Feruloyl esterases (E.C. 3.1.1.73), also known as ferulic acid esterases (FAE), cinnamoyl esterases, and cinnamic acid hydrolases, are a subclass of the carboxylic acid esterases (E.C. 3.1.1.1) that are able to hydrolyse the ester bond between hydroxycinnamic acids and sugars present in the plant cell walls [39-41]. Tannase 
(E.C.3.1.1.20) is an inducible microbial enzyme that hydrolyses ester and depside bonds in hydrolysable tannins to produce gallic acid and glucose [38]. This family includes fungal tannase and feruloyl esterase [42,43], several bacterial homologues of unknown function, and polyethylene terephthalate (PET) hydrolysing enzymes, e.g., the mono(2-hydroxyethyl) terephthalate hydrolase from the bacterium Ideonella sakaiensis $[44,45]$. In contrast to its homologous sequences, the MO13_Est631 shows a prolonged C-terminus (approximately 100 amino acids) uncharacteristic for most of the proteins in the tannase/feruloyl_esterase family, except for several hypothetical hydrolases from Variovorax, Serratia, and several other species. A truncated variant of this amidase-MO13_Est537, containing a 95-amino-acid deletion at the C-terminus-complemented the growth of uridine auxotrophic E. coli as efficiently as the wild-type variant (data not shown). Therefore, the trimmed MO13_Est537 protein was used for further characterization.

Of all 8 of the selected amidohydrolases, the most intriguing is the D8_RL enzyme: it is a 128-amino-acid uncharacterized protein without any predictable hydrolytic function. The amino acid sequence analysis using SMART [46] revealed that D8_RL contains the human activating signal cointegrator homology (ASCH) [47] and growth-arrest-specific protein 2 (GAS2) domains [48]. ASCH domain-containing proteins are widespread and diverse but, at present, the vast majority of those proteins have no function assigned to them [47], except for an ASCH domain-containing ribonuclease from Zymomonas mobilis [49] and a recently characterized unique ASCH domain-containing amidohydrolase YqfB from Escherichia coli, which is active towards $N^{4}$-acylcytidines [50]. The comparison of YqfB and D8_RL amino acid sequences showed merely 17 identical residues between these two proteins, and only 2 of the 4 YqfB catalytic amino acids were among them, although the aspartic acid residue in position 72 of the D8_RL and the catalytic glutamic acid residue in position 74 of the $\mathrm{YqfB}$ enzyme can also be considered conservative ones (Figure 3 and Figure S2).

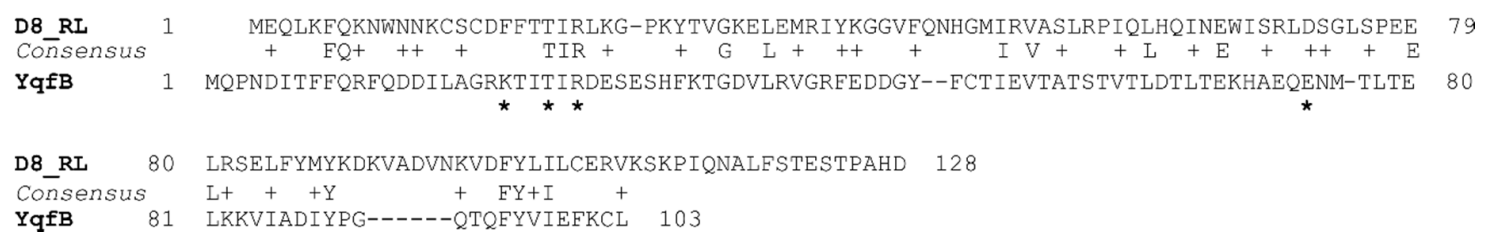

Figure 3. Alignment of tehe D8_RL and YqfB amino acid sequences. The catalytic amino acids of YqfB are marked by asterisks.

\subsection{Substrate Specificity of the Selected Amidohydrolases}

To confirm that the enzymes encoded in the selected fragments of the metagenomic DNA had the amidohydrolytic activity, their genes were PCR-amplified and the resulting fragments were ligated into pLATE31 or pET21a expression vectors. The BL21 (DE3) strain of E. coli was transformed with these plasmids and used for the synthesis of the recombinant amidohydrolase proteins. In total, 7 recombinant proteins were successfully purified by Ni-NTA chromatography (Figure S3). Due to its hydrophobic nature, the P4FUMM07_AmH protein was not purified to homogeneity, and a partially purified protein fraction was used for the activity assays.

The hydrolytic activity of the recombinant enzymes was assayed qualitatively by testing 29 different substrates (Figure 4A): $N^{4}$-acylated (2'-deoxy)cytidines and cytosines (1-16); $N^{2}$-acetylisocytosines (17); chromogenic substrates such as $p$-nitroacetanilide (18) and $p$-nitrobenzanilide (19); various p-nitrophenyl (pNP) esters (20-24); terephthalate derivatives bis(2-hydroxyethyl) terephthalate (26), dimethyl terephthalate (27), and monomethyl terephthalate (28); and the beta-lactam nitrocefin (29). Hydrolysis of chromogenic substrates (18-25) was analysed spectrophotometrically at $405 \mathrm{~nm}$, and that of other substrates was analysed spectrophotometrically at $240-320 \mathrm{~nm}$ and using TLC or HPLC-MS (Figures S4-S10). All the reactions were monitored up to $24 \mathrm{~h}$. 


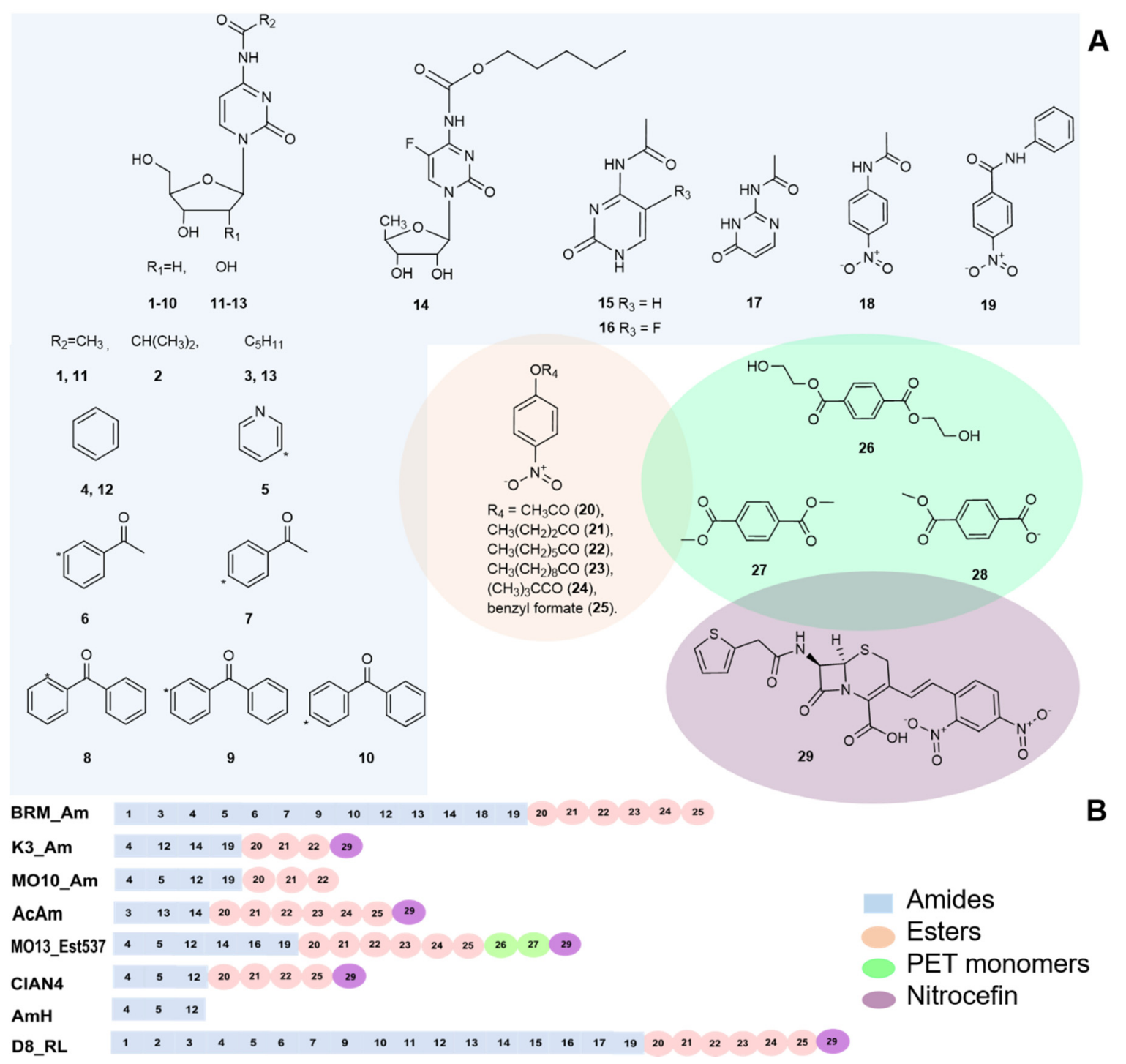

Figure 4. (A) Compounds tested as substrates for hydrolases. An asterisk marks the carbon atom through which the group was linked. (B) Substrate spectra of the individual hydrolases identified in this study. AcAm-P4FUMM07_AcAm, AmH_P4FUMM07_AmH.

The 8 hydrolases selected from the metagenomic libraries showed different activity profiles towards $\mathrm{N}$-acylated nucleosides harbouring short, bulky aliphatic, aromatic, and heterocyclic groups (Figure 4B). All of the identified enzymes, excluding the P4FUMM07_AcAm, hydrolysed $N^{4}$-benzoyl-2'-deoxycytidine (4) and were active towards $N^{4}$-benzoylcytidine (12) in vitro, therefore reiterating the experiments in vivo. In the case of the clone P4FUMM07, it could be concluded that the growth complementation of E. coli DH10B $\triangle p y r F E C:: K m$ cells depended on the activity of the amidohydrolase P4FUMM07_AmH, but not the P4FUMM07_AcAm. All tested hydrolases were not very strictly specific to 2'-hydroxylation of ribose; however, they preferred the nucleosides as substrates and most of the enzymes did not hydrolyse cytosine (15-16) or isocytosine (17) derivatives. Only the D8_RL amidohydrolase accepted heterocyclic base derivatives (15-17) as substrates. The bulkiness of the acyl group played a significant role, since the selected hydrolases were specific towards longer acyls in the case of aliphatic radicals $(\mathbf{1}, \mathbf{2}, \mathbf{3}, \mathbf{1 1}, \mathbf{1 3})$. $N^{4}$-acetyl-2'-cytidine (11) was slowly converted to cytidine by the hydrolase D8_RL only: $10 \%-20 \%$ of unhydrolyzed substrate was still observed after $24 \mathrm{~h}$ incubation with enzyme. Five of the tested enzymes recognized capecitabine (14) as a substrate. Hydrolysis of 2'-deoxycytidine derivative with pyridine carboxylic acid group (5) was catalysed by 6 enzymes, 
but only 2 hydrolases—BRM_Am and D8_RL—catalysed hydrolysis of 2'-deoxycytidine compounds with larger aromatic groups (6, 7, 9 and 10); however, $N^{4}$-(2-benzoyl-benzoyl)-2'-deoxycytidine (8) was not recognized as a substrate. Hence, not only the bulkiness, but also the structure of the acyls was important for the activity of the BRM_Am and D8_RL enzymes.

Five hydrolases (MO13_Est537, CIAN4, K3_Am, D8_RL, and P4FUMM07_AcAm) showed beta-lactamase activity in the presence of nitrocefin (29) [12,51,52]. This feature is common to class VIII of carboxylesterases [52].

Seven of the selected hydrolases recognized esters as substrates; only the P4FUMM07_AmH was a "true" amidohydrolase without any detected esterase activity. The enzymes were active towards the short-chain esters (20-22); most of them used compounds 24 and 25, but only 3 amidases-BRM_Am, MO13Est537, and D8_RL—hydrolysed the pNP-decanoate (23). Thus, the selected hydrolases were the most active towards short-chain esters, in contrast to the larger amides.

Among the identified enzymes, the MO13_Est537 showed distinguished catalytic properties: in addition to cytidine-based substrates, the enzyme hydrolysed dimethyl terephthalate (27) and bis(2-hydroxyethyl) terephthalate (26). However, it was not active towards monomethyl terephthalate (28). HHpred [53] analysis showed that the best structural homologues of MO13_Est537 were feruloyl esterases from Aspergillus oryzae (PDB [54] entries 3WMT_B and 6G21_A) [43] and mono(2-hydroxyethyl) terephthalate hydrolase (MHETase) from Ideonella sakaiensis (PDB entry 6QG9_I), the second key enzyme in degradation of PET [44,45]. However, the previously described MHETases are not active towards dimethyl and bis(2-hydroxyethyl) terephthalates: these compounds are degraded by PET hydrolases (PETases), which are unable to hydrolyse the mono-modified terephthalates [55-57]. Hence, it can be concluded that the hydrolase MO13_Est537 from this study belongs to MHETase group according to its amino acid sequence, but its substrate specificity is more similar to that of PETases. There is no data available on the ability of feruloyl esterases to hydrolyse dimethyl/monomethyl terephthalate and bis(2-hydroxyethyl) terephthalate.

\subsection{Catalytic Properties of the Amidohydrolase D8_RL}

A more detailed analysis of the D8_RL hydrolase was carried out. Its kinetic parameters and substrate specificity was compared to those of a recently characterized amidohydrolase YqfB [50]. The kinetic parameters of both D8_RL and YqfB are shown in Table 2. According to these data, it can be concluded that both enzymes exhibit similar catalytic efficiency in the case of $N^{4}$-benzoylated cytidines $(4,12)$, but, in contrast to D8_RL, the YqfB hydrolase is more active towards $N^{4}$-acetylated cytidine derivatives $(\mathbf{1}, \mathbf{1 1})$.

Table 2. Catalytic parameters of D8_RL and YqfB. Both recombinant enzymes contain C-terminal 6-His tags. Activity was measured in $50 \mathrm{mM}$ potassium phosphate buffer, $\mathrm{pH} 8.0$, at $22{ }^{\circ} \mathrm{C}$. Rate constants were calculated from experiments with at least 3 different initial concentrations of substrate, using a statistical significance value of 0.05 .

\begin{tabular}{|c|c|c|c|c|}
\hline Enzyme & Substrate & $K_{M}(\mathrm{M})$ & $k_{\text {cat }}\left(\mathrm{s}^{-1}\right)$ & $k_{\text {cat }} / K_{M}\left(\mathbf{M}^{-1} \mathbf{s}^{-1}\right)$ \\
\hline $\begin{array}{c}\text { D8_RL } \\
\text { YqfB }\end{array}$ & 1 & $\begin{array}{c}(3.0 \pm 1) \times 10^{-4} \\
(4.0 \pm 0.04) \times 10^{-4}\end{array}$ & $\begin{array}{c}0.08 \pm 0.01 \\
101 \pm 1\end{array}$ & $\begin{array}{c}(2.65 \pm 0.9) \times 10^{2} \\
(2.30 \pm 0.02) \times 10^{5}\end{array}$ \\
\hline $\begin{array}{l}\text { D8_RL } \\
\text { YqfB }\end{array}$ & 11 & $\begin{array}{c}\text { N.D. } \\
(6.2 \pm 0.1) \times 10^{-5}\end{array}$ & $\begin{array}{c}\text { N.D. } \\
157 \pm 1\end{array}$ & $\begin{array}{l}(6.5 \pm 3.4) \times 10^{1} \\
(2.2 \pm 0.1) \times 10^{6}\end{array}$ \\
\hline $\begin{array}{c}\text { D8_RL } \\
\text { YqfB }\end{array}$ & 4 & $\begin{array}{c}(5.0 \pm 0.2) \times 10^{-5} \\
(3.0 \pm 0.01) \times 10^{-4}\end{array}$ & $\begin{array}{c}0.37 \pm 0.2 \\
0.07 \pm 0.01\end{array}$ & $\begin{array}{l}(6.9 \pm 0.6) \times 10^{3} \\
(2.3 \pm 0.1) \times 10^{2}\end{array}$ \\
\hline $\begin{array}{c}\text { D8_RL } \\
\text { YqfB }\end{array}$ & 12 & $\begin{array}{c}(3.7 \pm 0.1) \times 10^{-5} \\
(5.1 \pm 0.03) \times 10^{-3}\end{array}$ & $\begin{array}{c}0.3 \pm 0.03 \\
1.8 \pm 0.1\end{array}$ & $\begin{array}{l}(5.7 \pm 0.4) \times 10^{3} \\
(3.5 \pm 0.7) \times 10^{3}\end{array}$ \\
\hline
\end{tabular}

N.D.-not determined. 
$N^{4}$-acetylcytidine not being a natural substrate of D8_RL enzyme might be the reason for the differences between the catalytic constants. The tremendous difference of the isoelectric points of these two small proteins-4.69 for YqfB (103 aa) and 9.00 for D8_RL (128 aa)—attracts attention, but the relationship between the structural features and the catalytic properties remains unclear. Keeping in mind that both proteins belong to the same ASCH family, but have very different features, further studies should be carried out to elucidate the peculiarities of these small hydrolases.

\section{Materials and Methods}

\subsection{Materials}

Restriction endonucleases HindIII, BamHI, and PstI, Phusion DNA polymerase, aLICator ${ }^{\mathrm{TM}}$ LIC Cloning and Expression System Kit 3, and PageRuler ${ }^{\mathrm{TM}}$ Prestained Protein Ladder were purchased from Thermo Fisher Scientific, Vilnius, Lithuania. Pierce ${ }^{\mathrm{TM}}$ Coomassie Plus (Bradford) Assay Reagent and HisPur ${ }^{\mathrm{TM}}$ Ni-NTA spin column were purchased from Thermo Fisher Scientific, Rockford, IL, USA. Nutrient medium was purchased from Carl Roth, Karlsruhe, Germany. ZR Soil Microbe DNA MidiPrep ${ }^{\mathrm{TM}}$ was purchased from Zymo Research, Freiburg, Germany. Oligonucleotides (Table S2) were purchased from Metabion, München, Germany. $N^{4}$-acetylcytidine, $N^{4}$-acetyl-2'-deoxycytidine, $N^{4}$-benzoyl-2'-deoxycytidine, $N^{4}$-isobutyryl-2'-deoxycytidine, and isocytosine were purchased from Combi-Blocks, San Diego, CA, USA. pNP-acyl esters, uridine, 2'-deoxycytidine $N^{4}$-benzoylcytidine, $N^{4}$-acetylcytosine, $p$-nitroacetanilide, and capecitabine were obtained from Sigma-Aldrich, St. Louis, MO, USA. $N^{4}$-hexanoyl-2'-deoxycytidine, $N^{4}$-nicotinoyl-2'-deoxycytidine, $N^{4}$-(2-acetyl-benzoyl)-2'-deoxycytidine, $N^{4}$-(3-acetyl-benzoyl)-2' -deoxycytidine, $N^{4}$-(4-acetyl-benzoyl)2'-deoxycytidine, $N^{4}$-(2-benzoyl-benzoyl)-2'-deoxycytidine, $N^{4}$-(3-benzoyl-benzoyl)-2'-deoxycytidine, and $N^{4}$-(4-benzoyl-benzoyl)-2'-deoxycytidine were synthesised as described previously [58]. $N^{2}$-acetylisocytosine and $N^{4}$-acetyl-5-fluorocytosine were prepared as published previously [50].

\subsection{Functional Screening of Metagenomic Libraries}

Metagenomic libraries were constructed from soil and sediment samples using pUC19 plasmid vector as described earlier [12]. The clones exhibiting amidohydrolase activity were identified using $\mathrm{M} 9$ medium $\left(33.9 \mathrm{~g} / \mathrm{L} \mathrm{Na}{ }_{2} \mathrm{HPO}_{4}, 15 \mathrm{~g} / \mathrm{L} \mathrm{KH}_{2} \mathrm{PO}_{4}, 5 \mathrm{~g} / \mathrm{L} \mathrm{NH}_{4} \mathrm{Cl}, 2.5 \mathrm{~g} / \mathrm{L} \mathrm{NaCl}, 0.2 \%\right.$ glucose, $0.2 \%$ casamino acids, $1 \mathrm{mM}$ IPTG), containing $100 \mu \mathrm{g} / \mathrm{mL}$ ampicillin, $40 \mu \mathrm{g} / \mathrm{mL}$ kanamycin, and $0.02 \mathrm{mg} / \mathrm{mL}$ $N^{4}$-benzoyl-2'-deoxycytidine (4) as a sole source of uridine, allowing only the growth of recombinants that could complement the uridine auxotrophy of the E. coli DH10B $\triangle p y r F E C:: \mathrm{Km}$ strain by hydrolysing the 2'-deoxycytidine amide.

\subsection{DNA Sequencing and Gene Annotation}

Nucleotide sequences were determined at Macrogen Europe, Netherlands, using the following sequencing primers: M13F-pUC (5'-GTTTTCCCAGTCACGAC-3'), M13R-pUC (5'-CAGGAAACAGCTATGAC-3'), T7 Promoter (5'-TAATACGACTCACTATAGGG-3'), T7 terminator (5'-TAATACGACTCACTATAGGG-3'), and LIC Reverse Sequencing primer, 24-mer (5'-GAGCGGATAACAATTTCACACAGG-3'). ORFs were analysed using Benchling [Biology Software] 2019, retrieved from https://benchling.com. A homology search was conducted using the Blast server retrieved from http://www.ncbi.nlm.nih.gov/BLAST [59]. Phylogenetic analysis was conducted using the Maximum Likelihood Tree routine of MEGA X software (Version 10.0.5) [60,61]. The sequence alignment was performed using ClustalW in MEGA X.

\subsection{Overexpression and Purification of Hydrolases}

Metagenomic amidases encoding genes were amplified with Phusion DNA polymerase using primers listed in Supplementary Table S2. The cloning and overexpression procedures were performed as described previously [12]. 


\subsection{Enzymatic Activity of Hydrolases}

The activity of hydrolases was analysed by incubating the enzyme with $1 \mathrm{mM}$ pNP-esters and amides: acetate, butyrate, valerate, decanoate, trimethylacetate, benzyl $p$-nitrophenyl carbonate, $p$-nitroacetanilide, and $p$-nitrobenzanilide (from $10 \mathrm{mM}$ stock in DMSO) in $50 \mathrm{mM}$ potassium phosphate buffer, $\mathrm{pH} 7.5$, at $37^{\circ} \mathrm{C}$ for $10-30 \mathrm{~min}$ in $100 \mu \mathrm{L}$ of reaction volume. Depending on the enzyme specificity for the substrate, the reaction mixture contained 5-300 ng of protein. The absorption of the reaction mixture at $405 \mathrm{~nm}$ was measured against enzyme-free blank to compensate for the substrate auto-hydrolysis [62]. The hydrolytic activity using acylcytidines/cytosines was assayed in reaction mixture, which consisted of $50 \mathrm{mM}$ potassium phosphate buffer, $\mathrm{pH} 7.5$, with $0.1-5 \mathrm{mM}$ substrate and 5-300 ng of protein as described earlier [50]. A kinetic study of D8_RL hydrolase was performed as described previously [50]. The reactions were started by adding an appropriate amount of protein to $50 \mathrm{mM}$ potassium phosphate buffer, $\mathrm{pH} 8.0$, supplemented with $0.1-0.5 \mathrm{mM}$ substrate. Then, a decrease in absorbance at $310 \mathrm{~nm}$ was recorded at $22{ }^{\circ} \mathrm{C}$. rModeler software (Ubique Calculus Ltd., Vilnius, Lithuania) was used for the calculation of the kinetic parameters.

\section{Conclusions}

In conclusion, a combination of a synthetic cytidine derivative and the uridine auxotrophic mutant of E. coli DH10B $\triangle p y r F E C$ allows for the functional selection of amidohydrolases from metagenomic libraries. The proposed selection method is a high-throughput method that is applicable for rapid processing of large metagenomic libraries and offers the possibility to discover representatives of enzymes belonging to both known families of amidases and novel protein groups. Hence, the unique metagenomic amidohydrolases D8_RL, BRM_Am, and MO13_Est631, which hydrolyse a wide spectrum of substrates, have been discovered. It is expected that the proposed method might be further optimized and tailored for the identification of the enzymes with the desired properties by using substrates of different structures, e.g., varying in acyl bulkiness or charge.

Supplementary Materials: The following are available online at http://www.mdpi.com/2073-4344/10/4/445/s1. Figure S1: Growth of the selected clones on the M9 medium. Figure S2: The alignment was performed by ClustalW software. Figure S3: Analysis of the purified amidohydrolases by SDS-PAGE. Figures S4-S8: HPLC-MS analysis of the activity of D8_RL amidohydrolase. Figures S9 and S10: HPLC-MS analysis of the activity of MO13_Est631 amidohydrolase. Table S1: Metagenomic libraries used in this work. Table S2: Primers used for the amplification of the genes of the selected amidohydrolases.

Author Contributions: Conceptualization, R.M. (Rolandas Meškys) and N.U.; methodology, R.M. (Rita Meškienė); formal analysis N.U., R.M. (Rita Meškienè) and M.T.; investigation, A.A., N.U. and R.M. (Rolandas Meškys); kinetics, R.S. and A.L.; draft preparation, N.U. and R.M. (Rolandas Meškys); review and editing, R.M. (Rolandas Meškys); visualization, N.U.; supervision, R.M. (Rolandas Meškys). All authors have read and agreed to the published version of the manuscript.

Funding: This research was supported by the Agency for Science, Innovation and Technology (Lithuania) through "Selection system for prodrug-enzyme" grant No. 31V-59/(1.78)SU-1687.

Acknowledgments: We thank D. Tauraite for the $N^{4}$-acyl deoxycytidine derivatives.

Conflicts of Interest: A. Laurynènas is an owner of Ubique Calculus Ltd., Lithuania. The rModeler software developed by this company was used for analysis of the experimental data. The other authors declare no conflict of Interest.

\section{References}

1. Locey, K.J.; Lennon, J.T. Scaling laws predict global microbial diversity. Proc. Natl. Acad. Sci. USA 2016, 113, 5970-5975. [CrossRef] [PubMed]

2. Nguyen, T.M.; Seo, C.; Ji, M.; Paik, M.-J.; Myung, S.-W.; Kim, J. Effective soil extraction method for cultivating previously uncultured soil bacteria. Appl. Environ. Microbiol. 2018, 84, 14. [CrossRef] [PubMed]

3. Colin, P.-Y.; Kintses, B.; Gielen, F.; Miton, C.M.; Fischer, G.; Mohamed, M.F.; Hyvönen, M.; Morgavi, D.P.; Janssen, D.B.; Hollfelder, F. Ultrahigh-throughput discovery of promiscuous enzymes by picodroplet functional metagenomics. Nat. Commun. 2015, 6, 1-12. [CrossRef] [PubMed] 
4. Bornscheuer, U.T. The fourth wave of biocatalysis is approaching. Philos. Trans. R. Soc. A 2018, 376, 20170063. [CrossRef] [PubMed]

5. Lorenz, P.; Eck, J. Metagenomics and industrial applications. Nat. Rev. Microbiol. 2005, 3, 510. [CrossRef] [PubMed]

6. de Carvalho, C.C.C.R. Whole cell biocatalysts: Essential workers from Nature to the industry. Microb. Biotechnol. 2017, 10, 250-263. [CrossRef]

7. Galperin, M.Y.; Koonin, E.V. From complete genome sequence to 'complete' understanding? Trends Biotechnol. 2010, 28, 398-406. [CrossRef]

8. Montella, S.; Amore, A.; Faraco, V. Metagenomics for the development of new biocatalysts to advance lignocellulose saccharification for bioeconomic development. Crit. Rev. Biotechnol. 2016, 36, 998-1009. [CrossRef]

9. Ngara, T.R.; Zhang, H. Recent Advances in Function-based Metagenomic Screening. Genom. Proteom. Bioinform. 2018, 16, 405-415. [CrossRef]

10. Aučynaitè, A.; Rutkienè, R.; Tauraitè, D.; Meškys, R.; Urbonavičius, J. Discovery of bacterial deaminases that convert 5-Fluoroisocytosine into 5-Fluorouracil. Front. Microbiol. 2018, 9, 2375. [CrossRef]

11. Aučynaitè, A.; Rutkienè, R.; Tauraitė, D.; Meškys, R.; Urbonavičius, J. Identification of a 2'-O-Methyluridine nucleoside hydrolase using the metagenomic libraries. Molecules 2018, 23, 2904. [CrossRef] [PubMed]

12. Urbelienè, N.; Kutanovas, S.; Meškienè, R.; Gasparavičiūtè, R.; Tauraitė, D.; Koplūnaitè, M.; Meškys, R. Application of the uridine auxotrophic host and synthetic nucleosides for a rapid selection of hydrolases from metagenomic libraries. Microb. Biotechnol. 2019, 12, 148-160. [CrossRef] [PubMed]

13. Buchholz, K. A breakthrough in enzyme technology to fight penicillin resistance-Industrial application of penicillin amidase. Appl. Microbiol. Biotechnol. 2016, 100, 3825-3839. [CrossRef] [PubMed]

14. Lin, C.-P.; Wu, Z.-M.; Tang, X.-L.; Hao, C.-L.; Zheng, R.-C.; Zheng, Y.-G. Continuous production of aprepitant chiral intermediate by immobilized amidase in a packed bed bioreactor. Bioresour. Technol. 2019, 274, 371-378. [CrossRef] [PubMed]

15. Mehta, P.K.; Bhatia, S.K.; Bhatia, R.K.; Bhalla, T.C. Bench scale production of nicotinic acid using a versatile amide-hydrolysing Geobacillus subterraneus RL-2a isolated from thermal spring of Manikaran, India. J. Mol. Catal. B Enzym. 2014, 105, 58-65. [CrossRef]

16. Tang, X.-L.; Jin, J.-Q.; Wu, Z.-M.; Jin, L.-Q.; Zheng, R.-C.; Zheng, Y.-G. Structure-based engineering of amidase from Pantoea sp. for efficient 2-Chloronicotinic acid biosynthesis. Appl. Environ. Microbiol. 2019, 85. [CrossRef]

17. Kang, X.-M.; Cai, X.; Liu, Z.-Q.; Zheng, Y.-G. Identification and characterization of an amidase from Leclercia adecarboxylata for efficient biosynthesis of L-phosphinothricin. Bioresour. Technol. 2019, 289, 121658. [CrossRef]

18. Ghonemy, D.H.E. Microbial amidases and their industrial applications: A Review. J. Med. Microbiol. Diagn. 2015, 4, 1. [CrossRef]

19. Gabor, E.M.; de Vries, E.J.; Janssen, D.B. Construction, characterization, and use of small-insert gene banks of DNA isolated from soil and enrichment cultures for the recovery of novel amidases. Environ. Microbiol. 2004, 6, 948-958. [CrossRef]

20. Krieg, L.; Ansorge-Schumacher, M.B.; Kula, M.-R. Screening for Amidases: Isolation and Characterization of a novel D-amidase from Variovorax paradoxus. Adv. Synth. Catal. 2002, 344, 965-973. [CrossRef]

21. Kang, X.-M.; Zhang, X.-J.; Hong, L.-L.; Peng, F.; Liu, Z.-Q.; Zheng, Y.-G. Establishment of a novel high-throughput screening method for the detection and quantification of L-phosphinothricin produced by a biosynthesis approach. Process Biochem. 2019, 76, 136-141. [CrossRef]

22. Tannières, M.; Beury-Cirou, A.; Vigouroux, A.; Mondy, S.; Pellissier, F.; Dessaux, Y.; Faure, D. A Metagenomic study highlights phylogenetic proximity of quorum-quenching and xenobiotic-degrading amidases of the AS-family. PLoS ONE 2013, 8, e65473. [CrossRef] [PubMed]

23. Zheng, R.-C.; Zheng, Y.-G.; Shen, Y.-C. A screening system for active and enantioselective amidase based on its acyl transfer activity. Appl. Microbiol. Biotechnol. 2007, 74, 256-262. [CrossRef] [PubMed]

24. Zapata-Pérez, R.; García-Saura, A.G.; Jebbar, M.; Golyshin, P.N.; Sánchez-Ferrer, Á. Combined whole-cell high-throughput functional screening for identification of new nicotinamidases/pyrazinamidases in metagenomic/polygenomic libraries. Front. Microbiol. 2016, 7, 1915. [CrossRef] [PubMed] 
25. Časaitè, V.; Sadauskas, M.; Vaitekūnas, J.; Gasparavičiūtè, R.; Meškienė, R.; Skikaitè, I.; Sakalauskas, M.; Jakubovska, J.; Tauraitè, D.; Meškys, R. Engineering of a chromogenic enzyme screening system based on an auxiliary indole-3-carboxylic acid monooxygenase. MicrobiologyOpen 2019, 8, e00795. [CrossRef] [PubMed]

26. Uchiyama, T.; Miyazaki, K. Product-induced gene expression, a product-responsive reporter assay used to screen metagenomic libraries for enzyme-encoding genes. Appl. Environ. Microbiol. 2010, 76, 7029-7035. [CrossRef] [PubMed]

27. Aučynaitè, A.; Rutkienè, R.; Gasparavičiūtè, R.; Meškys, R.; Urbonavičius, J. A gene encoding a DUF523 domain protein is involved in the conversion of 2-thiouracil into uracil. Environ. Microbiol. Rep. 2018, 10, 49-56. [CrossRef]

28. Ireton, G.C.; McDermott, G.; Black, M.E.; Stoddard, B.L. The structure of Escherichia coli cytosine deaminase11Edited by I. A. Wilson. J. Mol. Biol. 2002, 315, 687-697. [CrossRef]

29. Clark, K.; Karsch-Mizrachi, I.; Lipman, D.J.; Ostell, J.; Sayers, E.W. GenBank. Nucleic Acids Res. 2016, 44, D67-D72. [CrossRef]

30. UniProt Consortium. UniProt: A worldwide hub of protein knowledge. Nucleic Acids Res. 2019, 47, D506-D515. [CrossRef]

31. Pratt, R.F.; McLeish, M.J. Structural Relationship between the Active Sites of $\beta$-Lactam-Recognizing and Amidase Signature Enzymes: Convergent Evolution? Biochemistry 2010, 49, 9688-9697. [CrossRef] [PubMed]

32. Labahn, J.; Neumann, S.; Büldt, G.; Kula, M.-R.; Granzin, J. An alternative mechanism for Amidase Signature enzymes. J. Mol. Biol. 2002, 322, 1053-1064. [CrossRef]

33. Bracey, M.H.; Hanson, M.A.; Masuda, K.R.; Stevens, R.C.; Cravatt, B.F. Structural adaptations in a membrane enzyme that terminates endocannabinoid signaling. Science 2002, 298, 1793-1796. [CrossRef] [PubMed]

34. Shin, S. Structure of malonamidase E2 reveals a novel Ser-cisSer-Lys catalytic triad in a new serine hydrolase fold that is prevalent in nature. EMBO J. 2002, 21, 2509-2516. [CrossRef]

35. Curnow, A.W.; Hong, K.; Yuan, R.; Kim, S.; Martins, O.; Winkler, W.; Henkin, T.M.; Söll, D. Glu-tRNAGln amidotransferase: A novel heterotrimeric enzyme required for correct decoding of glutamine codons during translation. Proc. Natl. Acad. Sci. USA 1997, 94, 11819-11826. [CrossRef]

36. Seibert, C.M.; Raushel, F.M. Structural and catalytic diversity within the amidohydrolase superfamily ${ }^{+}$. Biochemistry 2005, 44, 6383-6391. [CrossRef]

37. Sugrue, E.; Fraser, N.J.; Hopkins, D.H.; Carr, P.D.; Khurana, J.L.; Oakeshott, J.G.; Scott, C.; Jackson, C.J. Evolutionary expansion of the amidohydrolase superfamily in bacteria in pesponse to the synthetic compounds molinate and diuron. Appl. Environ. Microbiol. 2015, 81, 2612-2624. [CrossRef]

38. de las Rivas, B.; Rodríguez, H.; Anguita, J.; Muñoz, R. Bacterial tannases: Classification and biochemical properties. Appl. Microbiol. Biotechnol. 2019, 103, 603-623. [CrossRef]

39. Crepin, V.F.; Faulds, C.B.; Connerton, I.F. Functional classification of the microbial feruloyl esterases. Appl. Microbiol. Biotechnol. 2004, 63, 647-652. [CrossRef]

40. Dilokpimol, A.; Mäkelä, M.R.; Aguilar-Pontes, M.V.; Benoit-Gelber, I.; Hildén, K.S.; de Vries, R.P. Diversity of fungal feruloyl esterases: Updated phylogenetic classification, properties, and industrial applications. Biotechnol. Biofuels 2016, 9, 231. [CrossRef]

41. Oliveira, D.M.; Mota, T.R.; Oliva, B.; Segato, F.; Marchiosi, R.; Ferrarese-Filho, O.; Faulds, C.B.; dos Santos, W.D. Feruloyl esterases: Biocatalysts to overcome biomass recalcitrance and for the production of bioactive compounds. Bioresour. Technol. 2019, 278, 408-423. [CrossRef] [PubMed]

42. Banerjee, A.; Jana, A.; Pati, B.R.; Mondal, K.C.; Das Mohapatra, P.K. Characterization of Tannase Protein Sequences of Bacteria and Fungi: An In Silico Study. Protein J. 2012, 31, 306-327. [CrossRef] [PubMed]

43. Suzuki, K.; Hori, A.; Kawamoto, K.; Thangudu, R.R.; Ishida, T.; Igarashi, K.; Samejima, M.; Yamada, C.; Arakawa, T.; Wakagi, T.; et al. Crystal structure of a feruloyl esterase belonging to the tannase family: A disulfide bond near a catalytic triad. Proteins Struct. Funct. Bioinforma. 2014, 82, 2857-2867. [CrossRef] [PubMed]

44. Palm, G.J.; Reisky, L.; Böttcher, D.; Müller, H.; Michels, E.A.P.; Walczak, M.C.; Berndt, L.; Weiss, M.S.; Bornscheuer, U.T.; Weber, G. Structure of the plastic-degrading Ideonella sakaiensis MHETase bound to a substrate. Nat. Commun. 2019, 10,1-10. [CrossRef]

45. Yoshida, S.; Hiraga, K.; Takehana, T.; Taniguchi, I.; Yamaji, H.; Maeda, Y.; Toyohara, K.; Miyamoto, K.; Kimura, Y.; Oda, K. A bacterium that degrades and assimilates poly(ethylene terephthalate). Science 2016, 351, 1196-1199. [CrossRef] [PubMed] 
46. Letunic, I.; Bork, P. 20 years of the SMART protein domain annotation resource. Nucleic Acids Res. 2018, 46, D493-D496. [CrossRef]

47. Iyer, L.M.; Burroughs, A.M.; Aravind, L. The ASCH superfamily: Novel domains with a fold related to the PUA domain and a potential role in RNA metabolism. Bioinforma. Oxf. Engl. 2006, 22, 257-263. [CrossRef]

48. Collavin, L.; Buzzai, M.; Saccone, S.; Bernard, L.; Federico, C.; DellaValle, G.; Brancolini, C.; Schneider, C. cDNA Characterization and Chromosome Mapping of the Human GAS2 Gene. Genomics 1998, 48, $265-269$. [CrossRef]

49. Kim, B.-N.; Shin, M.; Ha, S.C.; Park, S.-Y.; Seo, P.-W.; Hofmann, A.; Kim, J.-S. Crystal structure of an ASCH protein from Zymomonas mobilis and its ribonuclease activity specific for single-stranded RNA. Sci. Rep. 2017, 7, 1-10. [CrossRef]

50. Stanislauskienė, R.; Laurynėnas, A.; Rutkienè, R.; Aučynaitè, A.; Tauraitė, D.; Meškienė, R.; Urbelienė, N.; Kaupinis, A.; Valius, M.; Kaliniene, L.; et al. YqfB protein from Escherichia coli: An atypical amidohydrolase active towards N4-acylcytosine derivatives. Sci. Rep. 2020, 10, 1-12. [CrossRef]

51. Petersen, E.I.; Valinger, G.; Sölkner, B.; Stubenrauch, G.; Schwab, H. A novel esterase from Burkholderia gladioli which shows high deacetylation activity on cephalosporins is related to $\beta$-lactamases and dd-peptidases. J. Biotechnol. 2001, 89, 11-25. [CrossRef]

52. Ohlhoff, C.W.; Kirby, B.M.; Van Zyl, L.; Mutepfa, D.L.R.; Casanueva, A.; Huddy, R.J.; Bauer, R.; Cowan, D.A.; Tuffin, M. An unusual feruloyl esterase belonging to family VIII esterases and displaying a broad substrate range. J. Mol. Catal. B Enzym. 2015, 118, 79-88. [CrossRef]

53. Zimmermann, L.; Stephens, A.; Nam, S.-Z.; Rau, D.; Kübler, J.; Lozajic, M.; Gabler, F.; Söding, J.; Lupas, A.N.; Alva, V. A Completely reimplemented MPI bioinformatics toolkit with a new HHpred server at its core. J. Mol. Biol. 2018, 430, 2237-2243. [CrossRef] [PubMed]

54. Burley, S.K.; Berman, H.M.; Bhikadiya, C.; Bi, C.; Chen, L.; Di Costanzo, L.; Christie, C.; Dalenberg, K.; Duarte, J.M.; Dutta, S.; et al. RCSB Protein Data Bank: Biological macromolecular structures enabling research and education in fundamental biology, biomedicine, biotechnology and energy. Nucleic Acids Res. 2019, 47, D464-D474. [CrossRef] [PubMed]

55. Cheng, X.; Dong, S.; Chen, D.; Rui, Q.; Guo, J.; Wang, D.; Jiang, J. Potential of esterase DmtH in transforming plastic additive dimethyl terephthalate to less toxic mono-methyl terephthalate. Ecotoxicol. Environ. Saf. 2020, 187, 109848. [CrossRef]

56. Barth, M.; Oeser, T.; Wei, R.; Then, J.; Schmidt, J.; Zimmermann, W. Effect of hydrolysis products on the enzymatic degradation of polyethylene terephthalate nanoparticles by a polyester hydrolase from Thermobifida fusca. Biochem. Eng. J. 2015, 93, 222-228. [CrossRef]

57. Luo, Z.-H.; Wu, Y.-R.; Chow, R.K.K.; Luo, J.-J.; Gu, J.-D.; Vrijmoed, L.L.P. Purification and characterization of an intracellular esterase from a Fusarium species capable of degrading dimethyl terephthalate. Process Biochem. 2012, 47, 687-693. [CrossRef]

58. Jakubovska, J.; Tauraite, D.; Birštonas, L.; Meškys, R. N4-acyl-2'-deoxycytidine-5'-triphosphates for the enzymatic synthesis of modified DNA. Nucleic Acids Res. 2018, 46, 5911-5923. [CrossRef]

59. Altschul, S.F.; Gish, W.; Miller, W.; Myers, E.W.; Lipman, D.J. Basic local alignment search tool. J. Mol. Biol. 1990, 215, 403-410. [CrossRef]

60. Kumar, S.; Stecher, G.; Li, M.; Knyaz, C.; Tamura, K. MEGA X: Molecular Evolutionary Genetics Analysis across Computing Platforms. Mol. Biol. Evol. 2018, 35, 1547-1549. [CrossRef]

61. Thompson, J.D.; Higgins, D.G.; Gibson, T.J. CLUSTAL W: Improving the sensitivity of progressive multiple sequence alignment through sequence weighting, position-specific gap penalties and weight matrix choice. Nucleic Acids Res. 1994, 22, 4673-4680. [CrossRef] [PubMed]

62. Hernández-García, S.; García-García, M.I.; García-Carmona, F. An improved method to measure lipase activity in aqueous media. Anal. Biochem. 2017, 530, 104-106. [CrossRef] [PubMed]

(C) 2020 by the authors. Licensee MDPI, Basel, Switzerland. This article is an open access article distributed under the terms and conditions of the Creative Commons Attribution (CC BY) license (http://creativecommons.org/licenses/by/4.0/). 